集]膵炎研究モデルの作製，選択，適用

\title{
ハムスター膵癌細胞を用いた膵癌の転移特性の 解明および治療実験の意義
}

$\begin{array}{rrrrlr}\text { 内田 } & \text { 英二 } & \text { 松下 } & \text { 晃 } & \text { 柳 } & \text { 健 } \\ \text { 廣井 } & \text { 信 } & \text { 相本 } & \text { 隆幸 } & \text { 中村 } & \text { 慶春 } \\ \text { 福原 } & \text { 宗久 } & \text { 横山 } & \text { 正 } & \text { 田尻 } & \text { 孝* }\end{array}$

要 旨：膵癌は早期より転移を生じるため，その制御は予後改善に重要である．新しい観 点からの基礎的研究が行われているが, 特に分子生物学的知見からヒトへの応用までの過 程には実験モデルによる検証が必要である。われわれは N-nitrosobis (2-oxopropyl)amine （BOP）をシリアンゴールデンハムスターに皮下注射し発生させた膵癌から PGHAM-1 細 胞株を樹立した. PGHAM-1 細胞による膵癌モデルは, 病理学的特性㧍よび生物学的特性 もヒ卜膵癌に類似し, 膵内, 脾内, 腹胿内という 3 種類の同種移植方法によって, 膵腫疾, 肝転移, 腹膜播種というとト膵癌におけるすべての病態を 21 日という短期間で実験的に作 製できる。このモデルは, 転移特性の解明とともにその特性を生かした治療実験も可能で あり, 各種の血管新生阻害剤の治療実験でも, 転移率, 腫瘍径, 微小血管密度などの検討 から有用性が示された，動物を用いた研究モデルに関しては，実験動物をとりまく社会的 環境の変化からも，屠殺することなしに生体観察が可能な方法など，さらなる改善が望ま れている.

索引用語：膵癌実験モデル PGHAM-1 細胞 同種移植 転移特性 治療実験

\section{はじめに}

膵癌は早期発見が困難で, リンパ節および肝転 移，腹膜播種，局所再発を来しやすく，他の消化 器悪性疾患と比べて著しく予後が不良である。現 在，手術を中心に治療が進められているが，結果 は十分なものではなく, 新しい診断・治療法が求 められている ${ }^{1)}$.膵癌に対して様々な基礎的研究が 行われているが，最近の分子生物学的手法による 新知見は仮説検証の第一歩であり, ヒトへの適用 までの道のりは遠く, その結果を臨床的に応用す るまでのストラテジーが必要である. そのために は, in vitroから in vivo あるいは in vivo から臨床 応用への架け橋として, 疾患モデルを用いた動物

${ }^{*}$ 日本医科大学外科学講座 $($ 消化器 $\cdot$ 一般 $\cdot$ 乳腺 $\cdot$ 移植 部門）
実験は必要欠くべからざるものであり, 膵癌の 様々な害験モデルが考案されている ${ }^{2}$. 本稿では膵 癌実験モデルを概説するとともに, 膵癌転移制御 における PGHAM-1 細胞を用いたわれわれの実 験膵癌モデルの意義について述べる.

\section{膵癌動物モデル}

膵癌の疾患モデルとしては，様々なものがある が，最もよく知られているものは，Pour らによる 八ムスター膵発癌モデルである ${ }^{3}$.これは, ニトロ ソ化合物である発癌物質 N-nitrosobis (2-oxopropyl)amine（BOP）をシリアンゴールデンハムス ターに皮下注射し膵癌を発生させるもので, 発生 した膵癌は, 高分化型腺癌で, ヒトのものと形態 学的にきわめてよく類似するのみでなく, K-ras などの癌遺伝子の発現も認められるなど, 生物学 的特性でも一致し, 膵癌の組織発生の研究に使用 


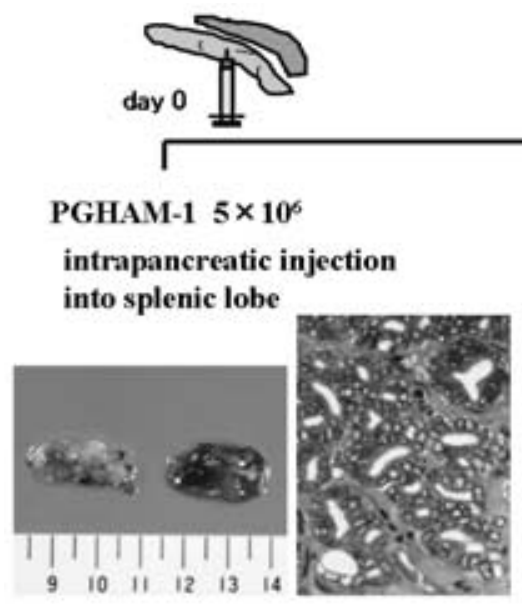

膵腫瘍 $100 \%$
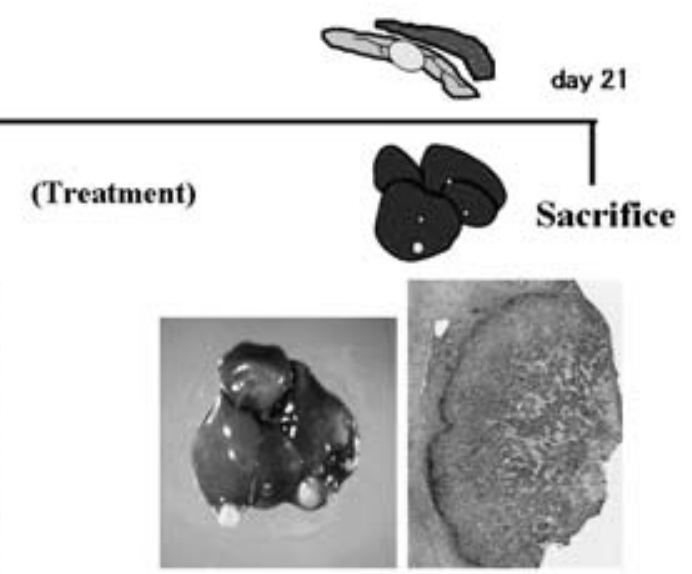

肝転移 $40 \sim 80 \%$

Fig. 1 PGHAM-1 膵内移植モデル

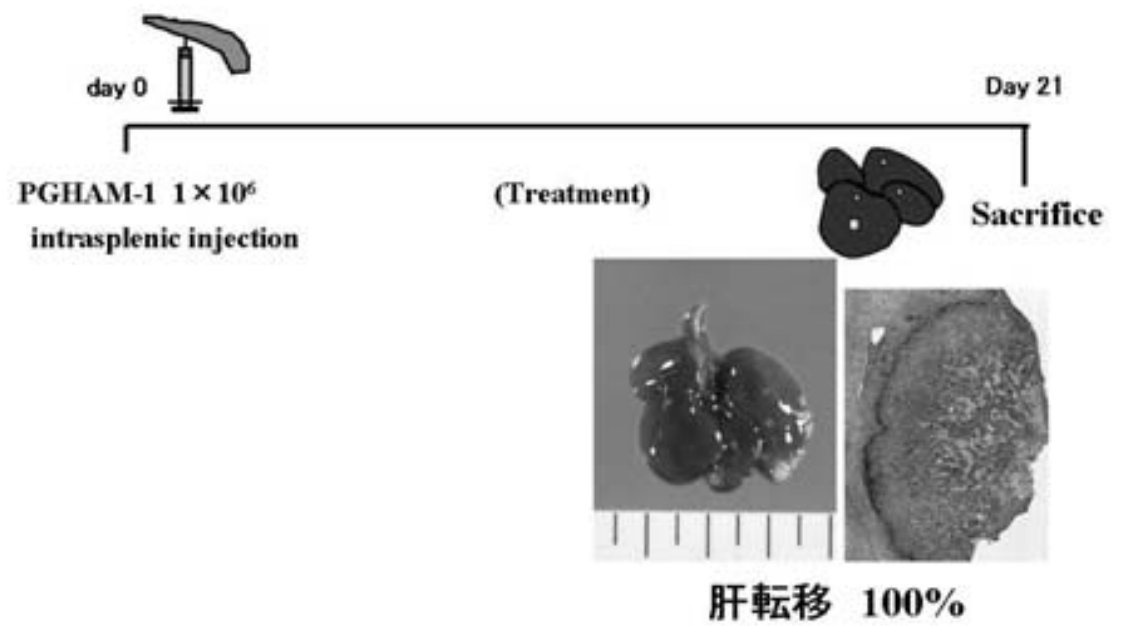

Fig. 2 PGHAM-1 脾内移植モデル

されている.このモデルでは BOP の単回あるい は複数回の投与にて, 高率に膵管癌を発生させる ことができるが, 発生までに 20 週程度の期間が必 要で，それを短縮するために様々な工夫がなされ てきだ)。また, 転移に関してはリンパ節, 肝転移 は認められるが, その頻度は少なく, 発癌までの 時間が長いことと相俟って, 転移の実験にはあま り適当とは思われない，他の膵癌動物モデルも，
ラットに化学発癌物質 azaserine, 4-hydroxyaminoquinoline-1-oxide（4-HAQO）を投与して腺 房細胞癌を発生させたもの, 7, 12-dimethylbenz (a) anthracene (DMBA) を直接膵内に埋没し, 腺 癌を発生させたものなど, 多くの報告")があるが, 八ムスターモデルを凌駕するものではなく, 現時 点では, BOPによる膵癌モデルが優れているとい うことができる. 


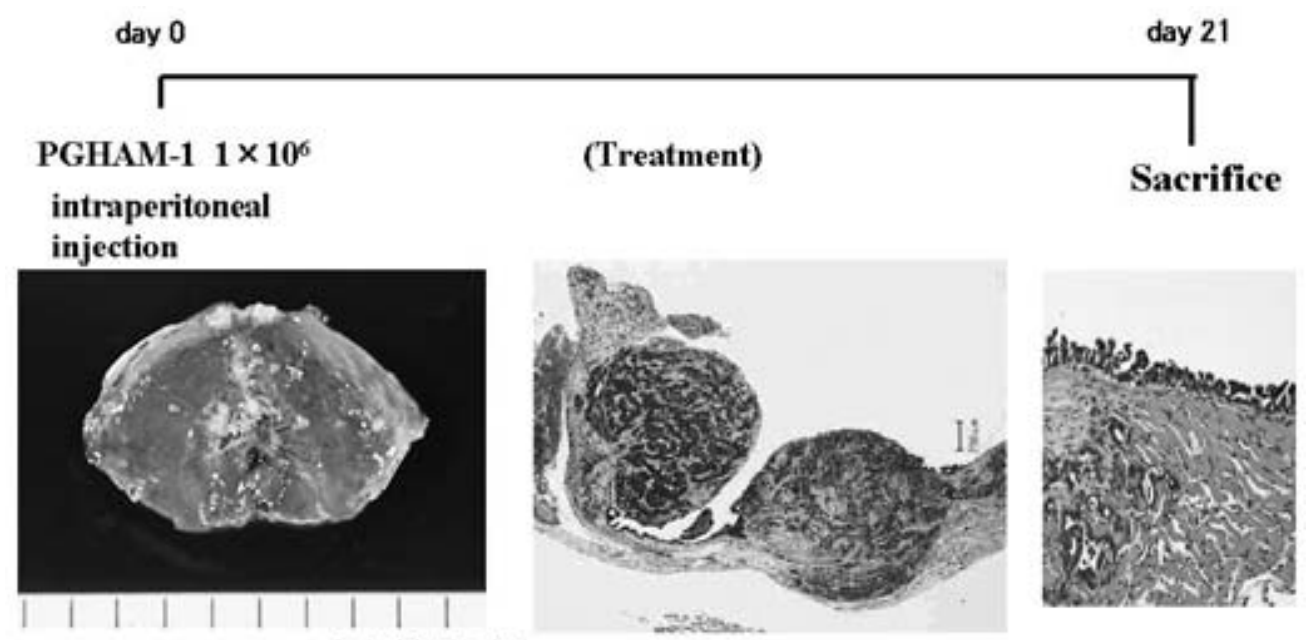

$100 \%$ (血性腹水)

Fig. 3 PGHAM-1 腹腔内移植モデル

Table 1 PGHAM - 1 細胞による各種移植モデル

\begin{tabular}{lccc}
\hline & 膵腫瘍 & 肝転移 & 腹膜播種 \\
\hline 膵内移植 & ++ & + & \pm \\
脾内移植 & - & ++ & - \\
腹腔内移植 & - & - & ++ \\
\hline
\end{tabular}

\section{PGHAM-1 細胞およびその特性}

われわれは，短期間で高率に転移を発生する脺 癌転移モデルを求めて, BOP 誘発膵癌組織を皮下 移植したものより, 移植可能な膵癌細胞株 PGHAM-1 を樹立し, 同細胞を同種移植すること で短期間で膵癌および転移を発生させる実験モデ ルを確立した ${ }^{5)}$. PGHAM-1 細胞は倍加時間が 14.4 時間と増殖能が高く, しかも PGHAM-1 細胞に よって形成される腫瘍も, 組織学的にヒト膵癌に 酷似し, 高浸潤能, 高転移能を持つうえ, K-ras codon12の点突然変異, vascular endothelial growth factor $(\mathrm{VEGF})^{6)}$, matrix metalloproteinase (MMP) 2, $9^{7}$ の発現という生物学的特性も併せ 持っていることがわかった。 また，同種膵内移植 により早期より，高率に肝転移を来すことが明ら かとなった。

\section{PGHAM-1 細胞による各種実験モデル}

PGHAM-1 細胞を用いた移植モデルには(1)膵 内移植モデル, (2)脾内移植モデル, (3)腹腔内移植 モデル，の3つの方法がある.

1) 膵内移植モデル : PGHAM-1 細胞 $5 \times 10^{6}$ 個 を同種ハムスターの膵脾葉に移植し, 膵原発巣と 肝転移を発生させるモデル（Fig. 1).

2) 脾内移植モデル：PGHAM-1を $1 \times 10^{6}$ 個同 種脾臓に移植し, 肝転移を発生させるモデル (Fig. 2).

3）腹腔内移植モデル：PGHAM-1を $1 \times 10^{6}$ 個 腹腔内に移植し, 腹膜播種を生じさせるモデル (Fig. 3).

いずれも, 移植後 21 日という短期間で形成させ ることができる（Table 1).

本モデルは, (1)ヒトとハムスターという種の差, (2)純粋な発癌からの転移ではない, という 2 点を 除けば, 宿主と癌細胞という関係において免疫系 も維持されていることからも，従来行われている ヒト膵癌細胞をヌードマウスに移植する転移実験 より, 組織浸潤, 転移形態に関しては自然であり, 膵癌の最適な転移モデルと考えている. 
1) Angiostatin group $(\mathrm{n}=10)$

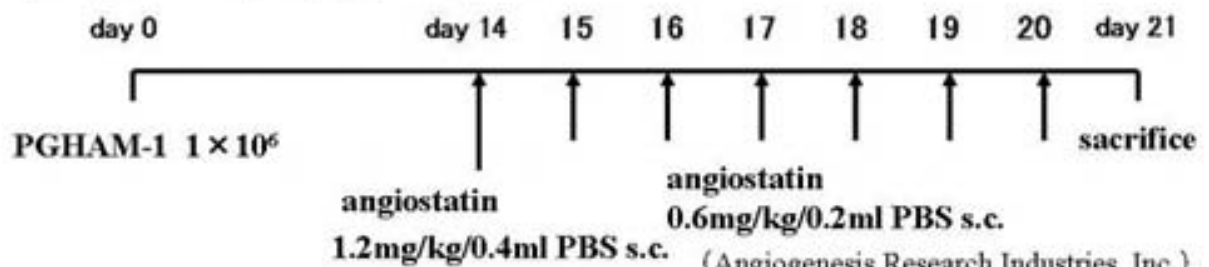

(Angiogenesis Research Industries, Inc.)

2) Control group $(n=15)$

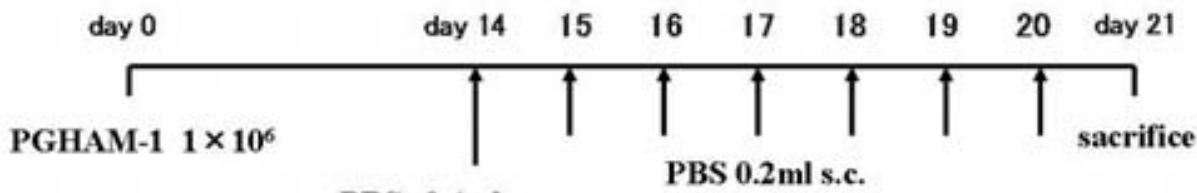

PBS $0.4 \mathrm{ml}$ s.c.

Fig. 4 PGHAM-1脾内移植モデルにおける angiostatinの効果に関する実験方法. PGHAM-1 細 胞 $\left(1 \times 10^{6}\right.$ 個)を 5 週齢の䧳性シリアンゴールデンハムスターの脾臓に移植し, angiostatin を皮下注射し, 移植後 21 日目に屠殺剖検し, 肝転移個数, 最大径, 微小血管密度, apoptotic index を比較した.

Table 2 PGHAM-1 移植モデルにおける各種血管新生阻害剂の効果

\begin{tabular}{|c|c|c|c|c|c|c|}
\hline 薬剂 & モデル & 膵腫瘍 & 肝移転 & 腹膜播種 & MVD & AI \\
\hline Angiostatin $^{8)}$ & 脾内 & - & $\downarrow$ & - & $\downarrow$ & $\uparrow$ \\
\hline $\mathrm{TNP}-470$ & 膵内 & $\downarrow$ & $\downarrow$ & - & $\mathrm{NE}$ & $\mathrm{NE}$ \\
\hline Thalidomide & 腹膜 & - & - & $\downarrow$ & $\downarrow$ & $\uparrow$ \\
\hline Tranilast ${ }^{9)}$ & 腹膜 & - & - & $\downarrow$ & $\downarrow$ & $\mathrm{NE}$ \\
\hline MMI-166 & 膵内 & $\downarrow$ & $\downarrow$ & - & $\downarrow$ & $\uparrow$ \\
\hline
\end{tabular}

MVD : microvessel density, AI : apoptotic index, NE : not examined

\section{転移特性の解明への応用}

本モデルの経時的観察をすることで, 転移の初 期像を捕らえることができる。われわれは，血管 新生に注目し, 特に, 血管内皮増殖因子 (VEGF) の発現と肝転移の関係を検討してみた。膵原発巣 で陽性であったVEGF は肝転移巣では減弱し, そ の腫瘍を膵内移植すると, 再びVEGF の発現は増 強した。これは，肝臓は血流が豊富であることか ら, 肝蔵においては癌細胞自体が VEGF を発現す る必要がないが, 再び膵蔵で発育するためには, VEGF が必要になると考えられた. 肝蔵という転 移先の状況が転移に大きな影響を与えていること を示している ${ }^{6}$.
また，腹膜播種モデルを用いると，この細胞に おける腹膜播種の初期像が容易に得られる。われ われは PGHAM-1 を用いたハムスター膵癌の腹 膜播種性転移形態には横隔膜，大網などにおける リンパ行性転移と, 壁側腹膜における直接接着と いう異なった機序による転移形態があり，それぞ れの転移に特有の過程を明らかにした。 また, 転 移が始まる時期は milky spotや stomata などの 解剖学的な吸収装置を介することにより, 直接接 着に対して時間的に, より早期に転移が起きるこ とを確認できた ${ }^{8)}$.

このように，本モデルを用いることは，転移特 性の解明を進める手段として有用と考えられた。 


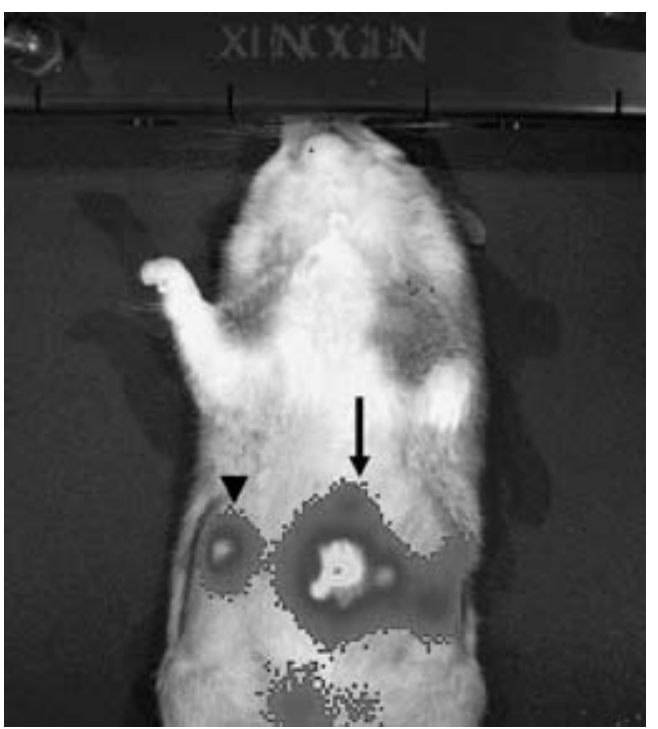

Fig. 5 PGHAM-1-Luc 細胞 $\left(5 \times 10^{6}\right.$ 個 $)$ を同種八 ムスター膵内移植後 14 日の IVIS imaging System (IVIS 100 System, Xenogen 社) に よる生体観察像. 膵腫瘍 $(\downarrow)$ と肝転移 を示す。

\section{治療実験への応用}

本モデルは, 転移特性の解明という点のみなら ず，その生物学的特性が類似し，短期間で膵腫瘍 およびその転移を発生させるため, 薬物の治療効 果の判定にも，使用可能と考えた。 その応用例と して，血管新生阻害鼡 (angiostatin)の膵癌に対す る効果の検討を提示する.使用する移植モデルは,

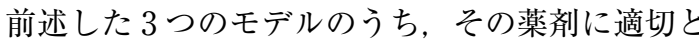
考えるものを使用するが, angiostatin では, 肝転 移モデルを使用した. Fig. 4 に示すようにangiostatin を投与し, 移植後 21 日の転移率, 転移腫 瘍最大径, 第 VIII 因子関連抗原染色による微小血 管密度(MVD)，TUNEL 法による apoptotic index を検討項目とした。 Angiostatinは転移率の減少, 腫瘍最大径の縮小, MVD の減少, apoptosisの増 強により，転移を抑制することが示された.

同様に, MMP-166 ${ }^{7}$, TNP-470, thalidomide, tranilas $\mathrm{t}^{10}$ についても行い, それぞれ効果が認めら れた．要約したものを Table 2 に示す.

このように，本モデルによって，短期間にin vivo における薬剤の効果を検討することができる
と考えている.

\section{今後の展開}

In vitroで見つけ出された事実をヒトに適用し ようとする場合には，in vivo の実験モデルによる 検証が必要とされてきた。近年, 動物愛護の観点 より, 厚生労働省, 文部科学省, などがそれぞれ 動物実験に対して, 厳格な規制を求めてきており, 以前のように簡単には実施できなくなってきてい る. 従って, 動物一頭の個体を充分に活用せねば ならず，このためには，個体を屠殺することなく， 実験経過を観察する方法が必要となろう。

われわれは，治療実験に応用するには，リアル タイムで状況を観察できるモデルが動物愛護の点 からも必要と痛感していた。 そこで, 新しいモデ ルとして, PGHAM-1 細胞にルシフェラーゼを遺 伝子導入し(PGHAM-1-Luc 細胞), in vivo イメー ジングを試みている (Fig. 5).このシステムを導入 し，これまでにわれわれが確立した 3 週間という 短期間の膵内移植，脾内移植，腹腔内移植実験乇 デルを使用することで, 新しい膵癌治療薬物のス クリーニングを生体観察によって行うことも可能 となろう。

\section{おわりに}

癌における動物モデルは, 発癌・浸潤・転移の メカニズムの解明に重要であり，経時的に検討で きる唯一の方法である. また，本モデルのように， 治療実験の導入にも必要なものであり, 今後も, 疾患モデルは in vitro からヒトへの応用の架け橋 として重要で有り続けると考えられる.

\section{文献}

1) Nakao A, Fujii T, Sugimoto H, et al. Oncologic problems in pancreatic cancer surgery. World J Gastroenterol 2006; 12: 4466-72.

2) 林 裕造, 高橋道人. 7 膵癌：B. 動物. 太田邦夫, 山 本 正, 杉村 隆, 菅野晴夫編. 癌の科学. 第 4 巻七 トの癌と動物モデル。東京：南江堂, 1979 : 258-70.

3) Pour PM, Wilson RB. Experimental tumors of the pancreas. In: Moosa AR, ed. Tumors of the pancreas. Baltimore: Williams and Wilkins, 1980: 37-159.

4) Mizumoto K, Tsutsumi M, Denda A, Konishi Y. Rapid production of pancreatic carcinoma by initiation with $\mathrm{N}$-nitrosobis(2-oxopropyl)amine and repeated augu- 
mentation pressure in hamsters. J Natl Cancer Inst 1988; 80: 1564-7.

5）横山 正, 恩田昌彦, 内田英二. 八ムスター膵癌株化 細胞 (PGHAM-1) を用いた短期同種膵内移植モデルの 作製とその経時的検討. 膵臟 $1996 ; 11: 411-20$.

6) Fukuhara M, Uchida E, Tajiri T, Aimoto T, Naito Z, Ishiwata $T$. Reexpression of reduced VEGF activity in liver metastasis of experimental pancreatic cancer. J Nippon Med Sch 2005; 72: 155-64.

7) Matsushita A, Onda M, Uchida E, Maekawa R, Yoshioka T. Antitumor effect of a new selective matrix metalloproteinase inhibitor, MMI-166, on experimen- tal pancreatic cancer. Int J Cancer 2001; 92: 434-40.

8) Yamamura S, Onda M, Uchida E. Two types of peritoneal dissemination of pancreatic cancer cells in a hamster model. J Nippon Med Sch 1999; 66: 253-61.

9) Yanagi K, Onda M, Uchida E. Effect of angiostatin on liver metastasis of pancreatic cancer in hamsters. Jpn J Cancer Res 2000; 91: 723-30.

10) Hiroi M, Onda M, Uchida E, Aimoto T. Anti-tumor effect of $\mathrm{N}-[3,4-$ dimethoxycinnamoyl]-anthranilic acid (tranilast) on experimental pancreatic cancer. J Nippon Med Sch 2002; 69: 224-34.

\title{
Hamster pancreatic cancer model for research on metastasis and therapeutic trials
}

\author{
Eiji UCHIDA, Akira MATSUSHITA, Ken YANAGI, \\ Makoto HIROI, Takayuki AIMOTO, Yoshiharu NAKAMURA, \\ Munehisa FUKUHARA, Tadashi YOKOYAMA, and Takashi TAJIRI*
}

Key words: Pancreatic cancer, Experimental model, Hamster, PGHAM-1 cell, Therapeutic experiment

We developed short-term pancreatic cancer models in hamsters using PGHAM-1 cells and estimated the utility of the models for research on metastasis and therapeutic trials. Using three PGHAM-1 models; 1) primary pancreatic cancer and simultaneous liver metastasis by intrapancreatic transplantation, 2) liver metastasis alone by intrasplenic transplantation, 3) peritoneal dissemination by intraperitoneal transplantation, within twenty-one days after inoculation, we studied the specific characteristics of metastases and the effect of several anti-angiogenic substances on primary and metastatic pancreatic tumors. Vascular endotherial growth factor and the anatomical character were important factors for metastasis. In the therapeutic experiment, the incidence, size, diameter, microvessel density (MVD), and apoptotic index of the tumors were preferably influenced by the anti-angiogenic substances. In addition, PGHAM-1-Luc, i.e., luciferase-positive PGHAM-1 cells, were newly developed. These models would be suitable not only for studying the pathogenesis and metastasis of pancreatic cancer but also for preclinical trials of chemotherapeutic agents such as anti-angiogenic substances.

\footnotetext{
* Department of Surgery, Nippon Medical School (Tokyo)
} 